\title{
Short communication: Heat stress does not affect induced luteolysis in Holstein cows
}

\author{
H. D. G. Mogollón, ${ }^{1}$ R. A. Ferrazza, ${ }^{1}$ V. H. Vallejo, ${ }^{1}$ F. C. Destro, ${ }^{1}$ J. C. Ochoa, ${ }^{1}$ C. Nogueira, ${ }^{1}$ R. F. Carvalho, ${ }^{2}$ \\ L. N. Moraes, ${ }^{3}$ G. Rizzoto, ${ }^{4}$ R. Sartori, ${ }^{5}$ M. C. Wiltbank, ${ }^{6}$ and J. C. P. Ferreira ${ }^{1 *}$ \\ ${ }^{1}$ Department of Animal Reproduction and Veterinary Radiology, School of Veterinary Medicine and Animal Science, \\ São Paulo State University (UNESP), Rua Prof. Dr. Walter Maurício Correa, s/n, 18618-681, Botucatu, SP, Brazil \\ ${ }^{2}$ Department of Morphology, Institute of Biosciences, University of Sao Paulo State (UNESP), R. Prof. Dr. Antônio Celso Wagner Zanin, 250, \\ Distrito de Rubião Junior, 18618-681, Botucatu, SP, Brazil \\ ${ }^{3}$ School of Agriculture, São Paulo State University (UNESP), 18610-034, Botucatu, SP, Brazil \\ ${ }^{4}$ Department of Production Animal Health, Faculty of Veterinary Medicine, University of Calgary, Calgary, AB, T3R 1J3, Canada \\ ${ }^{5}$ Department of Animal Science, Luiz de Queiroz College of Agriculture (ESALQ), University of São Paulo, Av. Pádua Dias, 11, 13418-900, \\ Piracicaba, SP, Brazil \\ ${ }^{6}$ Department of Animal and Dairy Sciences, University of Wisconsin, Madison 53706
}

\begin{abstract}
Heat stress (HS) has deleterious effects on bovine reproduction, including prolongation of the luteal phase in Holstein cows, perhaps due to compromised luteolysis. The objective was to characterize effects of HS on luteolytic responses of nonlactating Holstein cows given 25 or $12.5 \mathrm{mg}$ of $\mathrm{PGF}_{2 \alpha}$ on $\mathrm{d} 7$ of the estrous cycle. Cows were randomly distributed into 2 environments: thermoneutral $\left(\mathrm{n}=12 ; 25^{\circ} \mathrm{C}\right)$ or $\mathrm{HS}\left(\mathrm{n}=12 ; 36^{\circ} \mathrm{C}\right)$. In each environment, cows were treated with $2 \mathrm{~mL}$ of saline, 25 or $12.5 \mathrm{mg}$ of $\mathrm{PGF}_{2 \alpha}$ ( $\mathrm{n}=4$ cows per group). The HS environment induced a significant increase in rectal temperature and respiratory rate compared with the thermoneutral environment. Heat stress did not have significant effects on luteolytic responses or circulating progesterone concentrations. Rapid and complete luteolysis occurred in all cows given $25 \mathrm{mg}$ of $\mathrm{PGF}_{2 \alpha}$ and in 4 of 8 cows given $12.5 \mathrm{mg}$; the other 4 cows given 12.5 $\mathrm{mg}$ had partial luteolysis, with circulating progesterone concentrations initially suppressed, but subsequently rebounding. Therefore, we conclude that HS does not change corpus luteum sensitivity to $\mathrm{PGF}_{2 \alpha}$.
\end{abstract}

Key words: cattle, corpus luteum, progesterone, prostaglandin

\section{Short Communication}

Heat stress (HS) has a negative effect on production and reproduction of dairy cows, reducing production efficiency during warmer months (Roush, 1994; Hulme, 1997), as it reduces ovarian follicular growth

Received August 14, 2019.

Accepted January 16, 2020.

*Corresponding author: joao.cp.ferreira@unesp.br rate and plasma estradiol concentrations (Wilson et al., 1998a,b), and inhibits fertilization, embryonic development, and maternal recognition of pregnancy (Sartori et al., 2002). The few available studies regarding the effects of HS on duration of the estrous cycle do not share a common conclusion. Some studies indicate that lactating Holstein cows and heifers subjected to HS had a luteal phase $\sim 9 \mathrm{~d}$ longer than those in a thermoneutral (TN) environment, presumably due to effects of HS on luteolytic mechanisms (Wilson et al., 1998a,b). Another study reported lower circulating progesterone $(\mathbf{P} \mathbf{4})$ in the second half of the luteal phase in cows exposed to HS, attributing this effect to an earlier luteolysis (Wolfenson et al., 1988). On the other hand, one study found no effect of HS on estrous cycle length (Trout et al., 1998). Paradoxically, endometrial explants collected on the 17th day of the estrous cycle and subjected to in vitro $\mathrm{HS}$ produced more $\mathrm{PGF}_{2 \alpha}$ (Putney et al., 1988), which would presumably hasten luteolysis in vivo. However, in vitro HS increased P4 production by luteal cells without affecting their viability. Therefore, we hypothesized that changes in corpus luteum (CL) sensitivity to the luteolytic effects of $\mathrm{PGF}_{2 \alpha}$ account for the irregular luteal phases observed in heat-stressed cattle. The objective was to determine in vivo luteal responses of heat-stressed nonlactating Holstein cows challenged with 25 or $12.5 \mathrm{mg}$ of $\mathrm{PGF}_{2 \alpha}$ on $\mathrm{d} 7$ of the estrous cycle.

This experiment, conducted between October and December (2014) in the bioclimatic chamber of the Lageado Experimental Farm, was approved by the School of Veterinary Medicine and Animal Science, Sao Paulo State University (FMVZ-UNESP) Animal Care Committee No. 86/2013. Eighteen nonlactating, adult, clinically healthy Holstein cows with BCS 3, using a 1 (emaciated) to 5 (obese) scale according to Ferguson et 
al. (1994), were used. Cows were fed concentrate pellets and hay, with ad libitum access to drinking water and a mineral supplement.

After a 30-d interval for adaptation, ovulation was synchronized as previous described (Trevisol et al., 2015). Six cows with ovulation confirmed by ultrasonography (MyLab Five, Esaote, Italy) were selected and randomly assigned to 2 distinct environments: $\mathrm{TN}\left(\mathrm{n}=3,24^{\circ} \mathrm{C}\right)$ or $\mathrm{HS}\left(\mathrm{n}=3,36^{\circ} \mathrm{C}\right)$. On d 7 after GnRH challenge to initiate a new estrous cycle, cows from each environment were randomly allocated to 1 of the following treatments: saline $(2 \mathrm{~mL}$ of $0.9 \% \mathrm{NaCl}$ solution), $25 \mathrm{mg}$ of $\mathrm{PGF}_{2 \alpha}$ (Lutalyse, Zoetis, São Paulo, Brazil), or $12.5 \mathrm{mg}$ of $\mathrm{PGF}_{2 \alpha}$. The study followed a completely randomized design with 4 replicates, with 12 cows in each environment, and 3 cows for each treatment per environment. Cows used in the first replicate of the HS environment were not used subsequently, whereas those assigned to the TN group were re-used in the next replicate for the HS environment. Every day during the experimental period, rectal temperature (RT) and respiratory rate (RR) were recorded. Temperature-humidity index (THI) for each environment was determined as described by McDowell et al. (1976).

Blood samples were collected into heparinized tubes by venipuncture of coccygeal vessels immediately before and every $6 \mathrm{~h}$ posttreatment until $24 \mathrm{~h}$ and then every $12 \mathrm{~h}$ until $48 \mathrm{~h}$. Samples were immediately centrifuged $\left(1,500 \times g\right.$ for $30 \mathrm{~min}$ at $\left.4^{\circ} \mathrm{C}\right)$ and plasma stored at $-20^{\circ} \mathrm{C}$. Plasma $\mathrm{P} 4$ concentrations were determined using chemiluminescence (Immulite 1000, Immunoassay System, Siemens Healthcare, São Paulo, Brazil).
The variables THI, RT, RR, and circulating P4 were analyzed as repeated measures over time (Proc Mixed, SAS, version 9.1, SAS Institute Inc., Cary, NC). For RT and RR, the model included fixed effects of ambient temperature (AT), day, and their interaction. Because $\mathrm{P} 4$ data were not normally distributed, a natural log-transformation was performed. The transformed P4 data were then analyzed using a model with fixed effects of treatment, hour, and their interaction; ambient temperature was nonsignificant $(P>0.05)$ and was removed from the model. Covariance matrices were selected based on Akaike's information criterion, consistent Akaike's information criterion, and Bayesian information criterion, with comparisons between means done with pdiff. Results are presented as mean \pm standard error of the mean, with $P<0.05$ considered significant.

We observed AT and day effects $(P<0.001)$ for RT and RR, with an AT $\times$ day interaction for RT $(P<$ $0.005)$. On all evaluation days, values were greater $(P<$ $0.05)$ for HS compared with TN for THI $(87.8 \pm 0.3$ vs. $75.0 \pm 0.4)$, RT $\left(39.2 \pm 0.2\right.$ vs. $\left.38.3 \pm 0.1^{\circ} \mathrm{C}\right)$, and $\mathrm{RR}$ $(65.6 \pm 5.2$ vs. $35.1 \pm 5$ breaths per min; Figures $1 \mathrm{~A}$ and $\mathrm{B})$. For these end points, we also observed effects of treatment, hour, and their interaction $(P<0.0001)$.

Ambient temperature had no effect on circulating P4 on $\mathrm{d} 7,5 \mathrm{~d}$ after allocating cows to TN or HS environments $(2.4 \pm 0.3$ and $2.8 \pm 0.4 \mathrm{ng} / \mathrm{mL}$, respectively). After starting the treatments, greater circulating P4 $(P$ $<0.05)$ was observed for saline when compared with the other treatments from 12 to $36 \mathrm{~h}$ (Figure $2 \mathrm{~A}$ and $2 \mathrm{~B})$. Furthermore, half of the cows $(\mathrm{n}=4)$ given 12.5
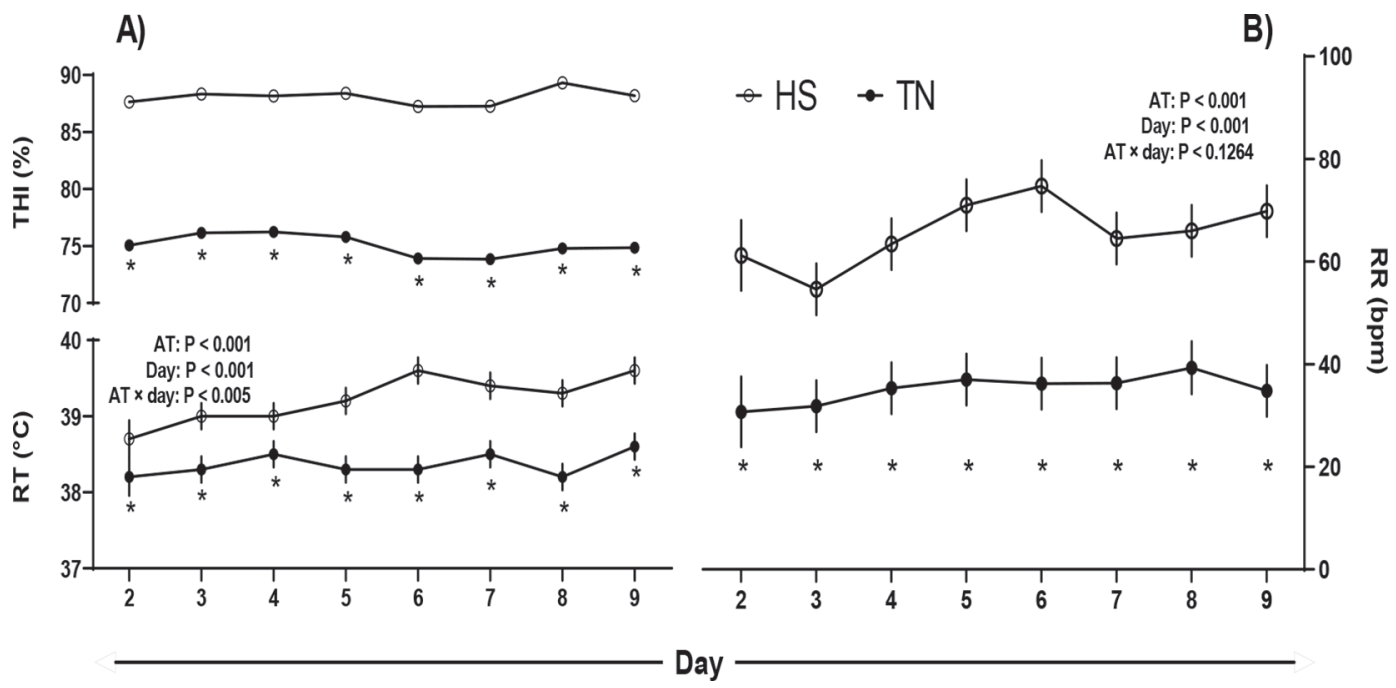

Figure 1. Mean \pm SEM for (A) temperature-humidity index (THI), rectal temperature $(\mathrm{RT})$, and $(\mathrm{B})$ respiratory rate $(\mathrm{RR}$; bpm $=$ breaths per minute) of nonlactating Holstein cows exposed to thermoneutral (TN, $\mathrm{n}=12$ ) or heat stress $(\mathrm{HS}, \mathrm{n}=12$ ) conditions. Probabilities for main effects [ambient temperature (AT) and day] and the interaction between AT and day are shown. Significant differences $(P<0.05)$ between TN and HS conditions are indicated by an asterisk $(*)$. 
mg of $\mathrm{PGF}_{2 \alpha}$ had complete luteolysis, whereas the remaining cows treated with $12.4 \mathrm{mg}$ of $\mathrm{PGF}_{2 \alpha}(\mathrm{n}=4)$ underwent partial luteolysis. The cows that had partial luteolysis had greater circulating $\mathrm{P} 4$ at 36 (Figure 2A) and $48 \mathrm{~h}$ after treatment compared with cows treated with $25 \mathrm{mg}$ of $\mathrm{PGF}_{2 \alpha}$ or cows treated with $12.5 \mathrm{mg}$ of

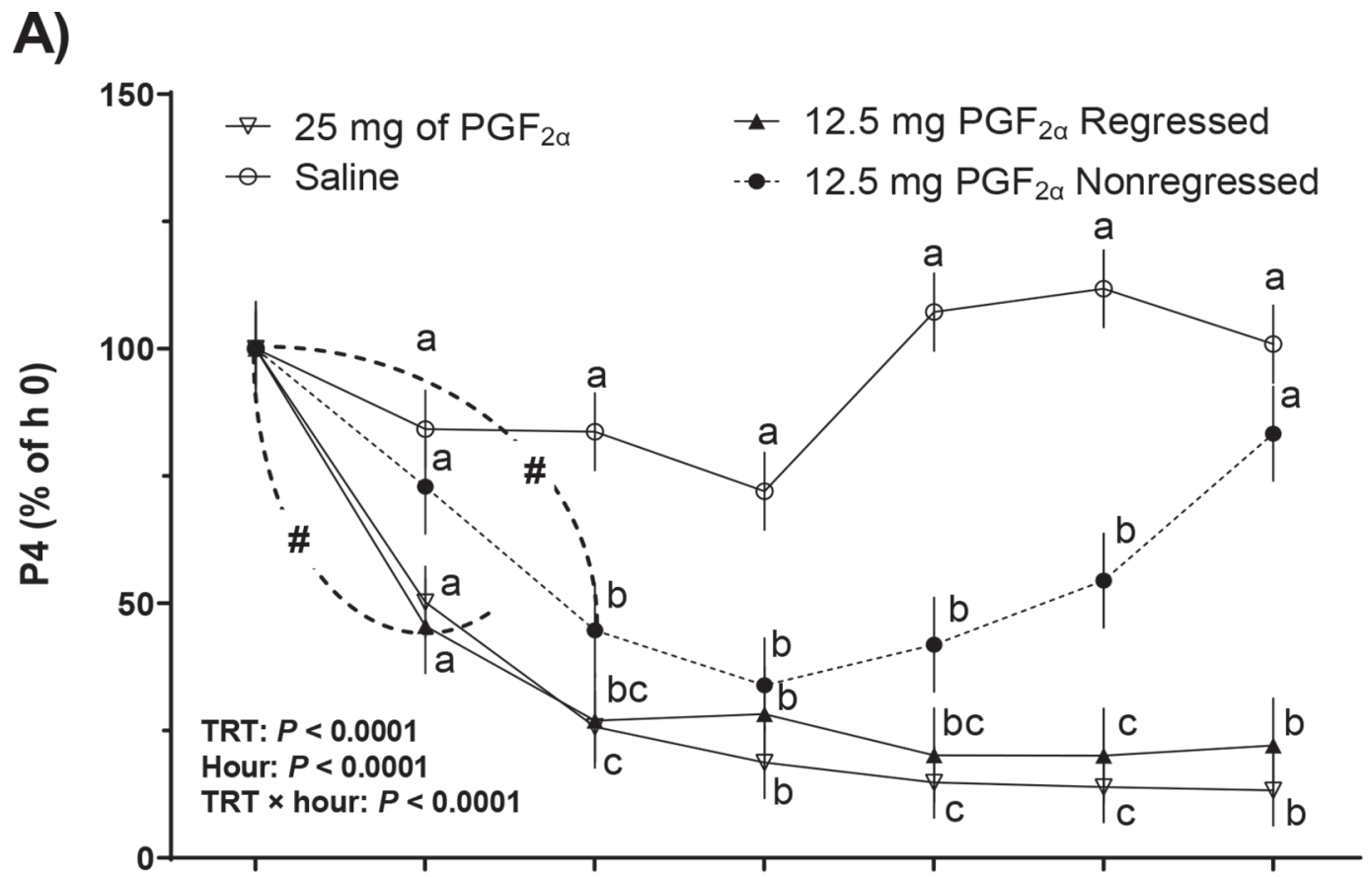

B)

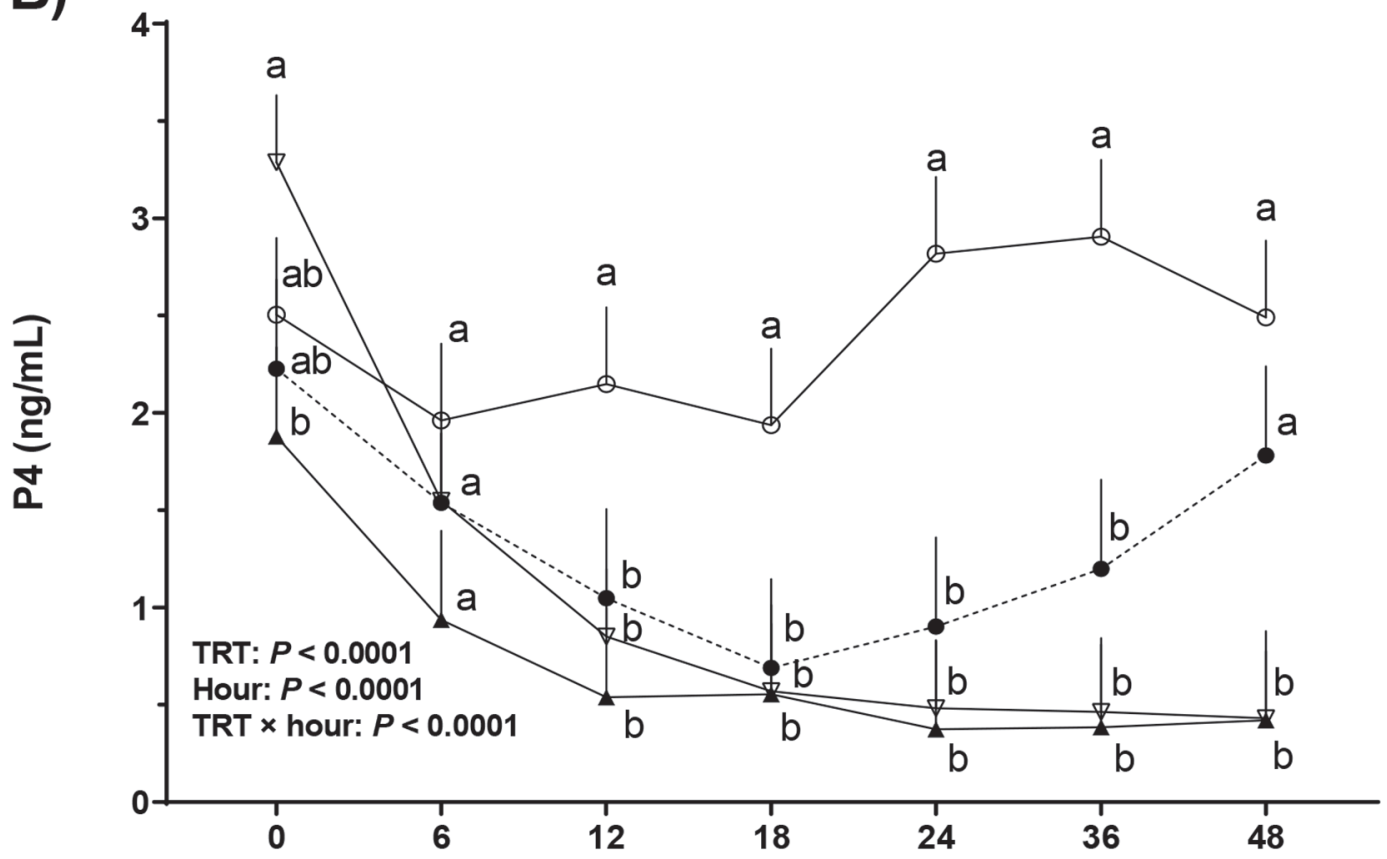

Hours after treatment

Figure 2. Circulating progesterone (P4) concentrations (\%) in relation to $0 \mathrm{~h}(\mathrm{~A})$ and mean $\pm \mathrm{SEM}$ of $\mathrm{P} 4 \mathrm{concentration}(\mathrm{ng} / \mathrm{mL}$; $\mathrm{B})$ of nonlactating Holstein cows after $\mathrm{PGF}_{2 \alpha}$ treatments on d 7. Saline $(\mathrm{n}=6), 25 \mathrm{mg}$ of $\mathrm{PGF}_{2 \alpha}(\mathrm{n}=7), 12.5 \mathrm{mg}$ of $\mathrm{PGF}_{2 \alpha}$ regressed $(\mathrm{n}=4)$, and $12.5 \mathrm{mg}$ of $\mathrm{PGF}_{2 \alpha}$ nonregressed $(\mathrm{n}=4)$. Probabilities for main effects [treatment (TRT) and hour], the interaction between TRT and hour, and the significant differences $(P<0.05)$ between treatments (different lowercase letters) and hours $(\#)$ are indicated. 
$\mathrm{PGF}_{2 \alpha}$ that had complete CL regression (Figure 2A and $2 \mathrm{~B}$ ). Cows with partial luteolysis had a decline in circulating $\mathrm{P} 4$ until $18 \mathrm{~h}$ posttreatment, followed by a subsequent rebound (Figure 2A). Last, circulating P4 was similar between cows given 25 versus cows given $12.5 \mathrm{mg}$ of $\mathrm{PGF}_{2 \alpha}$ that had complete regression (Figure $2 \mathrm{~A}$ and $\mathrm{B})$, except before treatment $(0 \mathrm{~h})$ when cows subsequently given $25 \mathrm{mg}$ of $\mathrm{PGF}_{2 \alpha}$ had greater $\mathrm{P} 4$ concentrations.

Furthermore, we detected that in the TN environment THI exceeded 72, regarded as the homeothermic limit for lactating Holstein cows (Staples and Thatcher, 2002). Regardless, cows in the present study did not display behavior indicative of $\mathrm{HS}$ and their RT and RR were $\sim 38.5^{\circ} \mathrm{C}$ and 37.3 breaths per minute, respectively, within physiological limits for Holstein cows $\left(\leq 39.5^{\circ} \mathrm{C}\right.$ and $<40$ breaths per minute; Dirksen et al., 1993). We attributed the lack of detectable HS symptoms to cows being nonlactating and nonpregnant. Greater thermotolerance and thermoregulatory capability of nonlactating cattle were also observed by Sartori et al. (2002) who reported Holstein heifers at $\sim 25^{\circ} \mathrm{C}$ ambient temperature had a $\mathrm{RT}<38.8^{\circ} \mathrm{C}$, whereas lactating cows had RT $>39.1^{\circ} \mathrm{C}$.

We observed that in the HS environment, during the first $48 \mathrm{~h}$ of exposure (average THI of 88), cows were able to maintain their RT within physiological limits. However, thermoregulatory capability was subsequently lost and RT increased, peaking on the 6th experimental day $\left(\sim 39.7^{\circ} \mathrm{C}\right)$, indicating that these cows were in the immediate phase of the HS response, characterized by poor adaptation to the environment and failure to maintain body temperature within physiological limits (Horowitz, 2002; Bernabucci et al., 2010).

Despite effectively inducing HS, we observed that the luteolytic responses to $\mathrm{PGF}_{2 \alpha}$ treatment (25 and 12.5 $\mathrm{mg}$ ) were not affected by the HS environment. Therefore, we concluded that changes in luteal susceptibility to $\mathrm{PGF}_{2 \alpha}$ were not the primary pathophysiological cause of the irregular luteal phase length in Holstein cows and heifers subjected to HS, which is in agreement with other studies (Wolfenson et al., 1988; Trout et al., 1998; Wilson et al., 1998a,b).

In addition, the similar circulating $\mathrm{P} 4$ concentrations observed on d 7 in cows assigned to TN or HS environments suggest that HS does not affect the production and metabolism of $\mathrm{P} 4$ during the early luteal phase. Another study (Trout at al., 1998) reported that circulating P4 in HS cows, from d 11 to 14 of the estrous cycle, was greater than that observed in control animals kept under TN conditions. However, these results are not necessarily comparable to our data due to the different diestrus period investigated. Last, the reduced circulating $\mathrm{P} 4(<1 \mathrm{ng} / \mathrm{mL})$ observed at $48 \mathrm{~h}$ posttreat- ment in cows treated with $12.5 \mathrm{mg}$ of $\mathrm{PGF}_{2 \alpha}$, followed by a subsequent rebound, was consistent with partial luteolysis, a well-described phenomenon in cattle (Meira et al., 2006; Wiltbank et al., 2012; Trevisol et al., 2015).

We conclude that exposure of nonlactating Holstein cows to an environment with a THI of $\sim 75$ did not induce HS. In contrast, a THI averaging 88 caused marked HS, characterized by increased RT and RR. Notwithstanding, HS had no significant effect on CL sensitivity to $\mathrm{PGF}_{2 \alpha}$. Independent of the environment, $25 \mathrm{mg}$ of $\mathrm{PGF}_{2 \alpha}$ induced complete luteolysis in all cows, whereas $12.5 \mathrm{mg}$ induced complete luteolysis in only half of the cows with the remainder having incomplete luteolysis and a subsequent rebound in circulating P4. These data did not support the assertion that HS changes CL sensitivity to the luteolytic effects of $\mathrm{PGF}_{2 \alpha}$.

\section{ACKNOWLEDGMENTS}

The authors acknowledge John Patrick Kastelic, University of Calgary (Calgary, AB, Canada) for reviewing the manuscript. This research was supported by São Paulo Research Foundation (FAPESP; Grant \#2011/20449-7, 2012/18297-7), Graduate Agreement Program (PEC-PG)/National Council for Scientific and Technological Development (CNPq; Grant \#190547/2012-0). The authors have not stated any conflicts of interest.

\section{REFERENCES}

Bernabucci, U., N. Lacetera, L. H. Baumgard, R. P. Rhoads, B. Ronchi, and A. Nardone. 2010. Metabolic and hormonal acclimation to heat stress in domesticated ruminants. Animal 4:1167-1183. https: //doi.org/10.1017/S175173111000090X.

Dirksen, G., H. D. Gründer, and M. Stöber. 1993. Rosenberger, Exame Clínico Dos Bovinos. 3rd ed. Guanabara, ed. Rio de Janeiro, Brazil.

Ferguson, J. D., D. T. Galligan, and N. Thomsen. 1994. Principal descriptors of body condition score in Holstein cows. J. Dairy Sci. 77:2695-2703. https://doi.org/10.3168/jds.S0022-0302(94)77212 $-\mathrm{X}$.

Horowitz, M. 2002. From molecular and cellular to integrative heat defense during exposure to chronic heat. Comp. Biochem. Physiol. A 131:475-483. https://doi.org/10.1016/S1095-6433(01)00500-1.

Hulme, M. 1997. Global warming. Prog. Phys. Geogr. 21:446-453. https://doi.org/10.1177/030913339702100309.

McDowell, R. E., N. W. Hooven, and J. K. Camoens. 1976. Effect of climate on performance of Holsteins in first lactation. J. Dairy Sci. 59:965-971. https://doi.org/10.3168/jds.S0022-0302(76)84305-6.

Meira, C., V. M. Pessoa, J. C. P. Ferreira, G. H. M. Araujo, M. M. Gioso, S. D. Bicudo, E. Oba, and C. Orlandi. 2006. Alternative low doses and routes of administering a prostaglandin F2 $\alpha$ analogue to induce luteolysis in Nelore cows. J. Vet. Sci. 7:387-390. https:/ /doi.org/10.4142/jvs.2006.7.4.387.

Putney, D. J., J. R. Malayer, T. S. Gross, W. W. Thatcher, P. J. Hansen, and M. Drost. 1988. Heat stress-induced alterations in the synthesis prostaglandins by cultured bovine conceptuses and secre- 
tion of proteins and uterine endometrium. Biol. Reprod. 39:717728. https://doi.org/10.1095/biolreprod39.3.717.

Roush, W. 1994. Population: The view from Cairo. Science 265:11641167. https://doi.org/10.1126/science.8066455.

Sartori, R., R. Sartor-Bergfelt, S. Mertens, J. Guenther, J. Parrish, and M. Wiltbank. 2002. Fertilization and early embryonic development in heifers and lactating cows in summer and lactating and dry cows in winter. J. Dairy Sci. 85:2803-2812. https://doi.org/10 .3168/jds.S0022-0302(02)74367-1.

Staples, C., and W. Thatcher. 2002. Effects on milk production and composition. Stress, Heat, In Dairy Cattle. Elsevier, Gainesville. $2592-2597$.

Trevisol, E., J. C. Ferreira, C. L. Ackermann, F. C. Destro, W. C. Marques Filho, A. S. Carmagos, M. V. Biehl, J. B. do Amaral, J. C. de Figueiredo Pantoja, R. Sartori, and J. C. P. Ferreira. 2015. Luteal changes after treatment with sub-luteolytic doses of prostaglandin (cloprostenol sodium) in cattle. Anim. Reprod. Sci. 153:8-12. https://doi.org/10.1016/j.anireprosci.2014.12.005.

Trout, J. P., L. R. McDowell, and P. J. Hansen. 1998. Characteristics of the estrous cycle and antioxidant status of lactating Holstein cows exposed to heat stress. J. Dairy Sci. 81:1244-1250. https:// doi.org/10.3168/jds.S0022-0302(98)75685-1.

Wilson, S. J., C. J. Kirby, A. T. Koenigsfeld, D. H. Keisler, and M. C. Lucy. 1998a. Effects of controlled heat stress on ovarian function of dairy cattle. 2. Heifers. J. Dairy Sci. 81:2132-8. https://doi.org/ 10.3168/jds.S0022-0302(98)75789-3.

Wilson, S. J., R. S. Marion, J. N. Spain, D. E. Spiers, D. H. Keisler, and M. C. Lucy. 1998b. Effects of controlled heat stress on ovarian function of dairy cattle. 1. Lactating cows. J. Dairy Sci. 81:21242131. https://doi.org/10.3168/jds.S0022-0302(98)75788-1.

Wiltbank, M. C., S. M. Salih, M. O. Atli, W. Luo, C. L. Bormann, J. S. Ottobre, and C. M. Vezina. 2012. Comparison of endocrine and cellular mechanisms regulating the corpus luteum of primates and ruminants. Anim. Reprod. 3:242-259.

Wolfenson, D., I. Flamenbaum, and A. Berman. 1988. Hyperthermia and body energy store effects on estrous behavior, conception rate, and corpus luteum function in dairy cows. J. Dairy Sci. 71:34973504. https://doi.org/10.3168/jds.S0022-0302(88)79956-7. 